\title{
Asthma and the immune response to MMR vaccine viruses in Somali immigrant children: a cross-sectional retrospective cohort study
}

\author{
Apurvi R Patel', John Zietlow ${ }^{2,3}$, Robert M Jacobson', Gregory A Poland ${ }^{4}$, *Young J Juhn'
}

\author{
1 Department of Pediatric and Adolescent Medicine, Mayo Clinic, Rochester, Minnesota, USA \\ ${ }^{2}$ Mercy Hospital, 4050 Coon Rapids Blvd, Coon Rapids, Minnesota, USA \\ ${ }^{3}$ Unity Hospital, 550 Osborne Road, Fridley, Minnesota, USA \\ ${ }^{4}$ Department of Internal Medicine, Mayo Clinic, Rochester, Minnesota, USA
}

Originally received 4th September 2012; resubmitted 21st November 2012; revised 19th December 2012; further revision 28th January 2013; accepted 5th February 2013; online 1st May 2013

\begin{abstract}
Background: According to the 'hygiene hypothesis', an increase in microbial exposure in childhood leads to a T-helper cell 1 (Th1) predominant immune response and protection against asthma and atopic conditions.

Aims: To assess the prevalence of asthma and other atopic conditions in Somali immigrants and to determine the humoral immune response to the measles, mumps, and rubella (MMR) vaccine viruses in Somali immigrants with asthma.

Methods: A retrospective cohort study was conducted in Olmsted County, Minnesota. Study subjects were Somali immigrants who were born and lived in Africa during childhood and immigrated to the USA. The subjects had participated in a previous MMR vaccine study. Asthma was ascertained using predetermined asthma criteria after a thorough medical record review. An atopic condition was determined from physiciandiagnosed ICD codes. Virus-specific IgG levels in response to the MMR vaccine viruses were determined using an enzyme immunoassay.

Results: Of the 62 eligible subjects, 33 (53\%) were female and 29 (47\%) were male; 10 (16\%) had asthma and 22 (35\%) had other atopic conditions. There was no difference in the rubella $(p=0.150)$ and measles $(p=0.715)$ virus-specific lgG levels between the subjects with and without asthma. Mumps virus-specific lgG antibody levels were lower in those with asthma than in those without asthma (mean \pm SE $2.08 \pm 0.28$ vs. $3.06 \pm 0.14, p=0.005)$.

Conclusions: Our study results may not support the hygiene hypothesis. In addition, the previously reported abnormal T-cell development in Caucasian children with atopy can be considered even in Somali immigrants.

(C) 2013 Primary Care Respiratory Society UK. All rights reserved.

AR Patel et al. Prim Care Respir J 2013; 22(3): 278-283

http://dx.doi.org/10.4104/pcrj.2013.00039
\end{abstract}

Keywords asthma, hygiene hypothesis, immunity, measles, mumps, rubella

\section{See linked editorial by Butler \& Francis on pg 262}

\section{Introduction}

The 'hygiene hypothesis' suggests that increased exposure to microbial infections in early childhood reduces the risk of T-helper cell 2 (Th2) predominant atopic conditions. ${ }^{1-3}$ Previous studies showed that, in united Germany, children from West Germany had an increased prevalence of atopic conditions and atopic sensitisation compared with those from East Germany. ${ }^{4,5}$ After reunification the prevalence of atopic conditions among children from West Germany increased, but the condition of those who spent early childhood in East Germany remained unchanged. These results suggest that environmental factors during early childhood might provide protection from atopic conditions. ${ }^{6}$ These findings were also observed in other parts of the world. ${ }^{7}$ Different lifestyles and environment during early childhood might therefore influence the subsequent risk of atopic conditions. However, few studies have been conducted to test the hygiene hypothesis using a natural experiment of African immigrants to a westernised country such as the USA. In the early 1990s a large number of Somali immigrants settled in the USA, including Olmsted County, Minnesota. The immigration of Somali

\footnotetext{
* Corresponding author: Dr Young J Juhn, Associate Professor, Department of Pediatric and Adolescent Medicine, Mayo Clinic, 200 First Street SW, Rochester, MN 55905, USA. Tel: +1 507-538-1642 Fax: +1 507-284-9744 E-mail: juhn.young@mayo.edu
} 
refugees allowed us to conduct the aforementioned natural experiment by assessing the prevalence of atopic conditions among this population.

Our recent study showed that Caucasian children with asthma had suboptimal immune responses to measles, mumps, and rubella (MMR) vaccine viruses. ${ }^{8}$ At present it is unknown whether or not Somali immigrants with asthma have similar immunological characteristics to those observed in their Caucasian counterparts. To address this question, we conducted a cross-sectional retrospective cohort study to assess the prevalence of asthma, allergic rhinitis, and atopic dermatitis among Somali immigrants and its relation to MMR vaccine virus-specific immunoglobulin $\mathrm{G}(\mathrm{lgG})$ levels.

\section{Methods}

\section{Study design and setting}

The study was designed as a retrospective cohort study with a crosssectional study component. According to the 2000 census, the population of Olmsted County, Minnesota was 124,277 (90.3\% white compared with $89.4 \%$ in the entire state of Minnesota and $75.1 \%$ in the USA). The characteristics of Olmsted County populations are similar to those of the US Caucasian population except that a higher proportion of the working population is employed in the healthcare industry. Medical care in Olmsted County is virtually self-contained within the community. All inpatient and outpatient data have been indexed in an automated form since 1935 under the Rochester Epidemiology Project., 9.10 This study protocol was approved by Institutional Review Boards at Mayo Clinic and Olmsted Medical Center.

\section{Study subjects}

The subjects were a convenience sample of 89 Somali immigrants who participated in a previous MMR vaccine study; the details of the subjects have been reported previously. ${ }^{11,12}$ Briefly, the original study cohort consisted of otherwise healthy individuals aged $<30$ years during the original vaccine study who had received a single dose of MMR vaccine after immigrating to the USA. Of the 89 original cohort subjects, 18 were not matched with clinic numbers from the two medical centers used in this study, eight subjects denied authorisation of medical record review for research, and one subject was born in Olmsted County and was therefore not considered to be a Somali immigrant. As a result, 27 subjects were excluded from the present study. No medical records from Somalia were available for these participants so the asthma and atopic condition status as well as immunisation record was unknown. Informed consent and/or assent was obtained from the subject and/or guardians.

Ascertainment of asthma and other atopic conditions We conducted a comprehensive medical record review for all subjects to collect pertinent data. Asthma status was ascertained by applying predetermined criteria for asthma, which has been widely used in studies for asthma epidemiology., ${ }^{8,13}$ The criteria for asthma are shown in Box 1. Ascertainment of atopic dermatitis or eczema and allergic rhinitis or hay fever was based on a physician diagnosis documented in the medical records. We also collected pertinent data to address the study aims such as demographic and clinical data.

\section{MMR vaccine virus-specific IgG levels}

Measles, mumps, and rubella-specific circulating lgG levels were

\section{Box 1. Definition of asthma}

Patients were considered to have definite asthma if a physician had made a diagnosis of asthma and/or if each of the following three conditions was present, and they were considered to have probable asthma if only the first two conditions were present:

1. History of cough, dyspnoea, and/or wheezing, OR history of cough and/or dyspnoea plus wheezing on examination,

2. Substantial variability in symptoms from time to time or periods of weeks or more when symptoms were absent, and

3. Two or more of the following:

- Sleep disturbance by nocturnal cough and wheeze

- Non-smoker (14 years or older)

- Nasal polyps

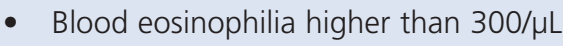

- Positive wheal and flare skin tests OR elevated serum $\lg \mathrm{E}$

- History of hay fever or infantile eczema OR cough, dyspnoea, and wheezing regularly on exposure to an antigen

- Pulmonary function tests showing one forced expiratory volume in one second (FEV1) or forced vital capacity (FVC) $<70 \%$ predicted and another with at least $20 \%$ improvement to an FEV1 of $>70 \%$ predicted OR methacholine challenge test showing $\geq 20 \%$ decrease in FEV1

- Favourable clinical response to bronchodilator

measured using ELISA. The details of the assay methods have been previously described. ${ }^{11}$ The median coefficient of variation among duplicate sample testing in our laboratory was 6.6\%.

\section{Statistical analysis}

We compared the prevalence of asthma, allergic rhinitis or hay fever, and atopic dermatitis or eczema between the study subjects with and without atopic conditions using a $\chi^{2}$ test. We subsequently compared MMR vaccine-specific lgG levels between subjects with and without asthma using ANCOVA to adjust the duration between the date of MMR vaccination and the time of measuring antibody levels. As a secondary analysis, we also assessed MMR vaccine virus-specific lgG levels between those with and without atopic conditions other than asthma.

\section{Results}

\section{Study subjects}

The characteristics of the study subjects are summarised in Table 1. Of the 62 eligible subjects, 29 (47\%) were male; the mean \pm SD age was $9.5 \pm 4.2$ years for children and 22 years for adults, and 48 (77\%) were under the age of 18 at the time of enrollment in the original study. The mean $\pm S D$ age of the study subjects at the time of migration from Somalia to the USA was $8.6 \pm 4.4$ years.

Prevalence of asthma and other atopic conditions

Of the 62 study subjects, 10 (16\%) had asthma and 22 (35\%) had 


\begin{tabular}{l} 
Table 1. Demographic and clinical characteristics of \\
study subjects \\
\begin{tabular}{ll} 
Characteristics & Study subjects $(\mathrm{n}=62)$ \\
\hline $\begin{array}{l}\text { Age, median (IQR) } \\
\text { Children }\end{array}$ & $9(6-9)$ \\
Adults & $22.5(20-25)$ \\
\hline Age group & \\
Children & $48(77 \%)$ \\
Adults & $14(23 \%)$ \\
\hline Gender (male) & $29(47 \%)$ \\
\hline Asthma & $10(16 \%)$ \\
Yes & $52(84 \%)$ \\
No &
\end{tabular} \\
\hline
\end{tabular}

\begin{tabular}{|c|c|}
\hline $\begin{array}{l}\text { Other atopic conditions (allergic } \\
\text { rhinitis or atopic dermatitis) } \\
\text { Yes } \\
\text { No }\end{array}$ & $\begin{array}{l}22(35 \%) \\
40(65 \%)\end{array}$ \\
\hline $\begin{array}{l}\text { Allergic rhinitis (or hay fever) } \\
\text { Yes } \\
\text { No }\end{array}$ & $\begin{array}{l}20(32 \%) \\
42(68 \%)\end{array}$ \\
\hline $\begin{array}{l}\text { Atopic dermatitis (eczema) } \\
\text { Yes } \\
\text { No }\end{array}$ & $\begin{array}{l}5(8 \%) \\
57(92 \%)\end{array}$ \\
\hline $\begin{array}{l}\text { Family history of asthma } \\
\text { Yes } \\
\text { No } \\
\text { Unknown }\end{array}$ & $\begin{array}{l}5(8 \%) \\
44(71 \%) \\
13(21 \%)\end{array}$ \\
\hline $\begin{array}{l}\text { Family history of atopy } \\
\text { Yes } \\
\text { No } \\
\text { Unknown }\end{array}$ & $\begin{array}{l}2(3 \%) \\
47(76 \%) \\
13(21 \%)\end{array}$ \\
\hline $\begin{array}{l}\text { Smoking exposure } \\
\text { Yes } \\
\text { No } \\
\text { Unknown }\end{array}$ & $\begin{array}{l}16(26 \%) \\
29(45 \%) \\
18(29 \%)\end{array}$ \\
\hline $\begin{array}{l}\text { Latent tuberculosis } \\
\text { Yes } \\
\text { No } \\
\text { Unknown }\end{array}$ & $\begin{array}{l}17(27 \%) \\
8(13 \%) \\
37(60 \%)\end{array}$ \\
\hline $\begin{array}{l}\text { Parasitic infections } \\
\text { Yes } \\
\text { No }\end{array}$ & $\begin{array}{l}3(5 \%) \\
59(95 \%)\end{array}$ \\
\hline $\begin{array}{l}\text { Co-morbid conditions } \\
\text { Yes } \\
\text { No }\end{array}$ & $\begin{array}{l}2(3 \%) \\
60(97 \%)\end{array}$ \\
\hline
\end{tabular}

other atopic conditions. All the subjects with asthma were children, whereas 18 children and four adults had other atopic conditions. The results are summarised in Table 1. Five subjects (8\%) were diagnosed with atopic dermatitis or eczema and 17 (27\%) were diagnosed with hay fever, allergic rhinitis, or allergic conjunctivitis.

\section{MMR vaccine virus-specific IgG levels}

The results are summarised in Table 2. The mumps virus lgG level in subjects with asthma was lower than in those without asthma, adjusting for the duration between MMR vaccination and blood draw for measurement of antibody. However, there were no differences in measles and rubella vaccine-specific IgG levels between subjects with and without asthma. Mumps virus-specific lgG antibody levels were slightly lower in individuals with other atopic conditions than in those without other atopic conditions (mean \pm SE $2.68 \pm 0.26$ vs. $3.02 \pm 0.15$ ), but the difference did not reach statistical significance $(p=0.216)$. There were no differences in measles vaccine-specific lgG levels and rubella vaccine-specific lgG levels between overall subjects with and without other atopic conditions ( $p=0.59$ and $p=0.31$, respectively).

\section{Discussion}

\section{Main findings}

We hypothesised that the Somali immigrants would have a lower prevalence rate of asthma and other atopic conditions than their Caucasian counterparts in our community due to increased microbial infections during early childhood since they spent their early childhood in Somalia (or other parts of Africa), given their mean age at the time of migration $(8.6 \pm 4.4$ years). However, Somali immigrants in our study, primarily children (77\%) with a mean age of 9 years, had a similar prevalence of asthma (16\%) to that in our community $(12.9-17.6 \%)^{20}$ and that of the USA (4-17\%) despite a relatively shorter duration of follow-up than Caucasian children born in the community. ${ }^{21,22}$ Similarly, the Somali immigrants had comparable prevalence rates of atopic dermatitis (8\%) and allergic rhinitis (27\%) to those in the USA (10-19\% atopic dermatitis and 26-33\% allergic rhinitis). ${ }^{23-25}$ In addition, we found that Somali immigrants with asthma had significantly lower anti-mumps virus-specific lgG levels than those without asthma. Therefore, in our study, increased exposure to microbial organisms during early childhood in the Somali immigrants (as supported by the high prevalence of latent tuberculosis) may not reduce the risk of atopic conditions based on this natural experiment, and the results are counter to the hygiene hypothesis.

\section{Strengths and limitations of this study}

The main strength of our study was the epidemiological advantage of

\begin{tabular}{|c|c|c|c|c|}
\hline & Asthmatics $(n=10)$ & Non-asthmatics $(n=52)$ & p Value (ANCOVA)* & $\begin{array}{l}\mathrm{p} \text { Value (Wilcoxon } \\
\text { rank sum test)** }\end{array}$ \\
\hline Mumps virus-specific IgG levels & $2.3(1.2-2.25)$ & $3.2(2.5-3.86)$ & 0.006 & 0.005 \\
\hline Measles virus-specific lgG levels & $2.0(1.36-2.35)$ & $1.9(1.43-2.11)$ & 0.753 & 0.702 \\
\hline Rubella virus-specific lgG levels & $2.8(2.63-3.17)$ & $2.6(2.45-2.80)$ & 0.126 & 0.092 \\
\hline \multicolumn{5}{|l|}{ Values are median (IQR). } \\
\hline \multirow{2}{*}{\multicolumn{5}{|c|}{ * $p$ value adjusted for duration between MMR vaccination and measurement of antibody levels using ANCOVA. }} \\
\hline \multicolumn{4}{|c|}{${ }^{* *} p$ value based on non-parametric test did not take into account the elapsed time since MMR vaccination. } & \\
\hline
\end{tabular}


our study setting, which includes a self-contained healthcare environment, availability of the entire medical records for research, and a relatively large population of Somali refugees. Another strength was the use of criteria-based asthma ascertainment instead of selfreport or a physician diagnosis alone. The data abstractor was blind to laboratory data (antibody levels) to avoid performance bias. Our study has inherent limitations as a retrospective study. We did not have data on previous immunisation records or potential past exposure to wild MMR viruses, nor did we have data on atopic sensitisation status and we did not assess other immunological parameters such as cell-mediated immunity. Our study was based on a small sample size which may have led to a type II statistical error. Because of the natural experiment, our study was based on Somali immigrants and the generalisability of our study findings might be limited to other populations or settings.

\section{Interpretation of findings in relation to previously published work}

The literature has been inconsistent in supporting ${ }^{26,27}$ and disputing ${ }^{28,29}$ the hygiene hypothesis. Recent studies suggest that the effect of microbial infections during early childhood on the risk of atopic conditions might be mediated through a gene-environmental interaction ${ }^{30}$ and epigenetic influences..$^{31}$ Our study could not address this aspect, but perhaps it would be interesting and important to assess the gene-environment interaction in this unique population group.

Studies have shown that mumps virus antibodies wane faster than those against the measles or rubella vaccine virus. ${ }^{32,33}$ Higher antibody levels against measles vaccine virus were seen than against mumps vaccine. ${ }^{34}$ The rationale for these differential immune responses among different vaccine viruses is unknown, and it is difficult to address given the small sample size and the potential of unknown exposure to previous MMR vaccines and wild MMR viruses. We postulate that the more rapid waning of humoral immunity against mumps virus than against measles and rubella viruses may show the systemic effect of asthma on humoral immunity earlier than its impact on humoral immunity against measles and rubella vaccine viruses. In support of this finding, we recently demonstrated that subjects with asthma had suboptimal cell-mediated immune response to measles, mumps, and rubella vaccine viruses after MMR vaccination ${ }^{8}$ and a more rapid waning of anti-measles virus-specific lgG levels than children without asthma. ${ }^{35}$ Noseworthy et al. conducted a cross-sectional study that assessed measles and mumps lgG levels among 48 children with asthma aged 1.6-17 years who had received two doses of MMR vaccine. The results showed that seronegativity in measles and mumps vaccine responses were $50-73 \%$ and $42-90 \%$, respectively, depending on the age of the children. ${ }^{36}$ Previous studies reported that Th2 cytokines or house dust mite sensitisation reduced humoral immune responses or antibody titres. ${ }^{37-39}$ Taken together, our study results may counter the hygiene hypothesis. For the previously reported inverse correlation between atopic tendency and the degree of delayed type hypersensitivity to Mycobacterium tuberculosis, ${ }^{40}$ our study results may imply abnormal T-cell development in atopics (resulting in potentially decreased immunity against mumps vaccine virus) as suggested by Prescott et al., which may still apply to Somali immigrants who may have had increased exposure to microbial infections during early childhood..$^{41,42}$ Further studies are needed in this area.

Implications for future research, policy and practice Our study results highlight the fact that a straightforward interpretation of the hygiene hypothesis should be made with caution, and the inverse correlation between immune responses to microbial agents and atopy tendency could be confounded by immune incompetence potentially associated with asthma. As recently suggested, the impact of asthma status or other atopic conditions on innate and humoral immune functions ${ }^{43-46}$ and susceptibility to microbial infections ${ }^{47-54}$ should be considered in understanding the relationship between microbial infection and the development of atopic diseases. Further research is needed to clarify the relationship.

\section{Conclusions}

Our study results may not support the hygiene hypothesis. The previously reported abnormal T-cell development in Caucasian children with atopy can be considered even in Somali immigrants who may have had increased exposure to microbial infections during early childhood. Assessment of the cell-mediated immune response to the MMR vaccine viruses in this population with and without asthma needs to be considered in a future study.

\section{Handling editor Dianne Goeman \\ Statistical review Gopal Netuveli}

Acknowledgements We thank the staff of the Pediatric Asthma Epidemiology Research Unit who made this study possible and Elizabeth Krusemark for administrative assistance.

Conflicts of interest GAP is the chair of a Safety Evaluation Committee for novel non-MMR vaccines undergoing clinical studies by Merck Research Laboratories. The authors declare that they have no conflicts of interest in relation to this article.

Contributorship ARP designed the study, collected data, interpreted the results, and wrote the manuscript. JZ collected data, reviewed the manuscript, and made editorial comments on the manuscript. RMJ designed the study, interpreted the results, reviewed the manuscript, and made editorial comments on the manuscript. GAP designed the study, interpreted the results, reviewed the manuscript, and made editorial comments on the manuscript. YJJ designed the study, interpreted the results, and wrote the manuscript.

Funding This work was supported by the Scholarly Clinician Award from the Mayo Foundation and made possible by the Rochester Epidemiology Project (R01AG034676) from the National Institute on Aging. This work was also supported by $\mathrm{NIH}$ grants N01-Al-40065, Al48793, and Al33144.

\section{References}

1. Vargas C, Bustos P, Diaz PV, Amigo H, Rona RJ. Childhood environment and atopic conditions, with emphasis on asthma in a Chilean agricultural area. J Asthma 2008:45(1):73-8. http://dx. doi.org/10.1080/02770900701752540

2. Umetsu DT, Mclntire JJ, Akbari O, Macaubas C, DeKruyff RH. Asthma: an epidemic of dysregulated immunity. Nat Immunol 2002;3(8):715-20. http://dx.doi.org/10.1038/ni0802-715

3. Falade AG, Ige OM, Yusuf BO, Onadeko MO, Onadeko BO. Trends in the prevalence and severity of symptoms of asthma, allergic rhinoconjunctivitis, and atopic eczema. J Natl Med Assoc 2009;101(5):414-18

4. Weiland SK, von Mutius E, Hirsch T, et al. Prevalence of respiratory and atopic disorders among children in the East and West of Germany five years after unification. Eur Respir J 1999;14(4):862-70. http://dx.doi.org/10.1034/j.1399-3003.1999.14d23.x

5. von Mutius E, Martinez FD, Fritzsch C, Nicolai T, Roell G, Thiemann HH. Prevalence of 
asthma and atopy in two areas of West and East Germany. Am J Respir Crit Care Med 1994;149(2 Pt 1):358-64. http://dx.doi.org/10.1164/ajrccm.149.2.8306030

6. Herberth $\mathrm{G}$, Hinz D, Roder $\mathrm{S}$, et al. Maternal immune status in pregnancy is related to offspring's immune responses and atopy risk. Allergy 2011;66(8):1065-74. http://dx.doi.org/10.1111/j.1398-9995.2011.02587.x

7. Steinman HA, Donson H, Kawalski M, Toerien A, Potter PC. Bronchial hyperresponsiveness and atopy in urban, peri-urban and rural South African children. Pediatr Allergy Immunol 2003;14(5):383-93.

http://dx.doi.org/10.1034/J.1399-3038.2003.00062.x

8. Yoo KH, Agarwal K, Butterfield M, Jacobson RM, Poland GA, Juhn YJ. Assessment of humoral and cell-mediated immune response to measles-mumps-rubella vaccine viruses among patients with asthma. Allergy Asthma Proc 2010;31(6):499-506. http://dx.doi.org/10.2500/aap.2010.31.3399

9. Melton $\sqcup$, 3rd. History of the Rochester Epidemiology Project. Mayo Clinic Proc 1996;71(3):266-74. http://dx.doi.org/10.4065/71.3.266

10. St Sauver JL, Grossardt BR, Yawn BP, Melton $\sqcup$ 3rd, Rocca WA. Use of a medical records linkage system to enumerate a dynamic population over time: the Rochester epidemiology project. Am J Epidemiol 2011;173(9):1059-68. http://dx.doi.org/10.1093/aje/kwq482

11. Dhiman N, Ovsyannikova IG, Vierkant RA, Pankratz VS, Jacobson RM, Poland GA. Associations between cytokine/cytokine receptor single nucleotide polymorphisms and humoral immunity to measles, mumps and rubella in a Somali population. Tissue Antigens 2008;72(3):211-20. http://dx.doi.org/10.1111/j.1399-0039.2008.01097.x

12. St S, Jacobson RM, Vierkant RA, Jacobsen SJ, Green EM, Poland GA. Association of parental vaccination reports with measles, mumps, and rubella protective antibody levels: comparison of Somali immigrant, Hispanic migrant, and US children in Rochester, Minn. Mayo Clin Proc 2002;77(3):241-5. http://dx.doi.org/10.4065/77.3.241

13. Juhn YJ, Kita H, Lee LA, et al. Childhood asthma and measles vaccine response. Ann Allergy Asthma Immunol 2006;97(4):469-76. http://dx.doi.org/10.1016/\$1081-1206(10)60937-4

14. Yunginger JW, Reed CE, O'Connell EJ, Melton LJ 3rd, O'Fallon WM, Silverstein MD. A community-based study of the epidemiology of asthma. Incidence rates, 19641983. Am Rev Respir Dis 1992;146(4):888-94. http://dx.doi.org/10.1164/ajrccm/146.4.888

15. Silverstein MD, Reed CE, O'Connell EJ, Melton LJ 3rd, O'Fallon WM, Yunginger JW. Long-term survival of a cohort of community residents with asthma. N Engl J Med 1994;331(23):1537-41. http://dx.doi.org/10.1056/NEJM199412083312301

16. Juhn YJ, Kita H, Yawn BP, et al. Increased risk of serious pneumococcal disease in patients with asthma. J Allergy Clin Immunol 2008;122(4):719-23. http://dx.doi.org/10.1016/j.jaci.2008.07.029

17. Jung JA, Kita H, Yawn BP, et al. Increased risk of serious pneumococcal disease in patients with atopic conditions other than asthma. J Allergy Clin Immunol 2010;125(1):217-21. http://dx.doi.org/10.1016/j.jaci.2009.10.045

18. Lynch BA, Van Norman CA, Jacobson RM, Weaver AL, Juhn YJ. Impact of delay in asthma diagnosis on health care service use. Allergy Asthma Proc 2010;31(4):e4852. http://dx.doi.org/10.2500/aap.2010.31.3358

19. Jung $J A$, Kita $H$, Dhillon $R$, et al. Influence of asthma status on serotype-specific pneumococcal antibody levels. Postgrad Med 2010;122(5):116-24. http://dx.doi.org/10.3810/pgm.2010.09.2208

20. Yawn BP, Wollan P, Kurland M, Scanlon P. A longitudinal study of the prevalence of asthma in a community population of school-age children. J Pediatr 2002;140(5):576-81. http://dx.doi.org/10.1067/mpd.2002.123764

21. Lethbridge-Çejku M, Vickerie J. Summary health statistics for U.S. adults: National Health Interview Survey, 2003. National Center for Health Statistics. Vital Health Stat 2005;10(225).

22. Forecasted state-specific estimates of self-reported asthma prevalence--United States, 1998. MMWR Morb Mortal Wkly Rep 1998;47:1022-5.

23. Hanifin JM, Reed ML. A population-based survey of eczema prevalence in the United States. Dermatitis 2007;18(2):82-91. http://dx.doi.org/10.2310/6620.2007.06034

24. Nathan R, Meltzer E, Derebery J, et al. Prevalence of nasal symptoms in the United States: findings from the Burden of Allergic Rhinitis in America Survey. J Allergy Clin Immunol 2008;121(2, Suppl 1):S208-9. http://dx.doi.org/10.1016/j.jaci.2007.12.777

25. Gordon B, Blaiss M, Meltzer E, Mahr T, Boyle J. Prevalence of seasonal and perennial allergic rhinitis in children and adults. J Allergy Clin Immunol 2008;121(2, Suppl 1):S209. http://dx.doi.org/10.1016/j.jaci.2007.12.778

26. Riedler J, Braun-Fahrlander C, Eder W, et al. Exposure to farming in early life and development of asthma and allergy: a cross-sectional survey. Lancet 2001;358(9288):1129-33. http://dx.doi.org/10.1016/S0140-6736(01)06252-3

27. Herbst $T$, Sichelstiel A, Schar C, et al. Dysregulation of allergic airway inflammation in the absence of microbial colonization. Am J Respir Crit Care Med 2011;184(2):198-205. http://dx.doi.org/10.1164/rccm.201010-15740C

28. Lemanske RF, Jr. Is asthma an infectious disease?: Thomas A. Neff lecture. Chest 2003;123(3 Suppl):385-90S. http://dx.doi.org/10.1378/chest.123.3_suppl.385S-a

29. Umetsu DT. Flu strikes the hygiene hypothesis. Nat Med 2004;10(3):232-4. http://dx.doi.org/10.1038/nm0304-232

30. Custovic A, Rothers J, Stern D, et al. Effect of day care attendance on sensitization and atopic wheezing differs by Toll-like receptor 2 genotype in 2 population-based birth cohort studies. J Allergy Clin Immunol 2011;127(2):390-7, e391-9.

31. Miller RL, Ho SM. Environmental epigenetics and asthma: current concepts and call for studies. Am J Respir Crit Care Med 2008;177(6):567-73. http://dx.doi.org/10.1164/rccm.200710-1511PP

32. Davidkin I, Jokinen S, Broman M, Leinikki P, Peltola H. Persistence of measles, mumps, and rubella antibodies in an MMR-vaccinated cohort: a 20-year follow-up. J Infect Dis 2008;197(7):950-6. http://dx.doi.org/10.1086/528993

33. LeBaron CW, Beeler J, Sullivan BJ, et al. Persistence of measles antibodies after 2 doses of measles vaccine in a postelimination environment. Arch Pediatr Adolesc Med 2007;161(3):294-301. http://dx.doi.org/10.1001/archpedi.161.3.294

34. Date AA, Kyaw MH, Rue AM, et al. Long-term persistence of mumps antibody after receipt of two measles-mumps-rubella (MMR) vaccinations and antibody response after a third MMR vaccination among a university population. J Infect Dis 2008;197(12):1662-8. http://dx.doi.org/10.1086/588197

35. Yoo KH, Jacobson RM, Poland GA, Juhn YJ. The impact of asthma status on durability of measles vaccine response in children. Abstract 485. Paper presented at the 2011 Annual European Allergy, Asthma and Clinical Immunology; Istanbul, Turkey.

36. Noseworthy ME, Henderson AM, Kanzira P, Ratnam S, Hamed AA. Measles, mumps and mycoplasma antibody profile in children with asthma. Poster C67. Paper presented at the Annual American Thoracic Society Meeting, 2005; San Diego, California.

37. Khan AQ, Shen Y, Wu ZQ, Wynn TA, Snapper CM. Endogenous pro- and antiinflammatory cytokines differentially regulate an in vivo humoral response to Streptococcus pneumoniae. Infect Immun 2002;70(2):749-61. http://dx.doi.org/10.1128/IAI.70.2.749-761.2002

38. Hales BJ, Chai LY, Elliot CE, et al. Antibacterial antibody responses associated with the development of asthma in house dust mite-sensitised and non-sensitised children. Thorax 2012;67(4):321-7. http://dx.doi.org/10.1136/thoraxjnl-2011-200650

39. Jung J, Kita $H, N a h m ~ M$, et al. Influence of asthma status on serotype specific antibody pneumococcal antibody levels. Postgrad Med 2010;122(5):116-24. http://dx.doi.org/10.3810/pgm.2010.09.2208

40. Shirakawa T, Enomoto T, Shimazu S, Hopkin JM. The inverse association between tuberculin responses and atopic disorder. Science 1997;275(5296):77-9. http://dx.doi.org/10.1126/science.275.5296.77

41. Holt PG, Clough JB, Holt BJ, et al. Genetic 'risk' for atopy is associated with delayed postnatal maturation of T-cell competence. Clin Exp Allergy 1992;22(12):1093-9. http://dx.doi.org/10.1111/j.1365-2222.1992.tb00135.x

42. Prescott SL, Sly PD, Holt PG. Raised serum IgE associated with reduced responsiveness to DPT vaccination during infancy. Lancet 1998;351(9114):1489. http://dx.doi.org/10.1016/S0140-6736(05)78871-1

43. Contoli M, Message SD, Laza-Stanca $V$, et al. Role of deficient type III interferonlambda production in asthma exacerbations. Nat Med 2006;12(9):1023-6. http://dx.doi.org/10.1038/nm1462

44. Sykes A, Edwards MR, Macintyre J, et al. Rhinovirus 16-induced IFN-alpha and IFNbeta are deficient in bronchoalveolar lavage cells in asthmatic patients. J Allergy Clin Immunol 2012;129(6):1506-14.e6.

45. Swindle EJ, Collins JE, Davies DE. Breakdown in epithelial barrier function in patients with asthma: identification of novel therapeutic approaches. J Allergy Clin Immunol 2009;124(1):23-34; quiz 35-6. http://dx.doi.org/10.1016/j.jaci.2009.05.037

46. Wark PA, Johnston SL, Bucchieri F, et al. Asthmatic bronchial epithelial cells have a 
deficient innate immune response to infection with rhinovirus. J Exp Med 2005;201(6):937-47. http://dx.doi.org/10.1084/jem.20041901

47. Juhn YJ, Frey D, Li X, Jacobson R. Streptococcus pyogenes upper respiratory infection and atopic conditions other than asthma: a retrospective cohort study. Prim Care Respir J 2012;21(2):153-8. http://dx.doi.org/10.4104/pcrj.2011.00110

48. Capili $C R$, Hettinger $A$, Rigelman-Hedberg $N$, et al. Increased risk of pertussis in patients with asthma. I Allergy Clin Immunol 2012;129(4):957-63. http://dx.doi.org/10.1016/j.jaci.2011.11.020

49. Juhn YJ, Kita $\mathrm{H}$, Yawn BP, et al. Increased risk of serious pneumococcal disease in patients with asthma. I Allergy Clin Immunol 2008;122(4):719-23. http://dx.doi.org/10.1016/j.jaci.2008.07.029

50. Chen CF, Wu KG, Hsu MC, Tang RB. Prevalence and relationship between allergic diseases and infectious diseases. J Microbiol Immunol Infect 2001;34(1):57-62.
51. Jung JA, Kita $H$, Yawn BP, et al. Increased risk of serious pneumococcal disease in patients with atopic conditions other than asthma. J Allergy Clin Immunol 2010;125(1):217-21. http://dx.doi.org/10.1016/j.jaci.2009.10.045

52. Jounio $U$, Juvonen $R$, Bloigu $A$, et al. Pneumococcal carriage is more common in asthmatic than in non-asthmatic young men. Clin Respir J 2010;4(4):222-9. http://dx.doi.org/10.1111/j.1752-699X.2009.00179.x

53. Frey $D$, Jacobson R, Poland $G$, Li X, Juhn Y. Assessment of the association between pediatric asthma and Streptococcus pyogenes upper respiratory infection. Allergy Asthma Proc 2009;30(5):540-5. http://dx.doi.org/10.2500/aap.2009.30.3268

54. Bjur KA, Lynch RL, Fenta YA, et al. Assessment of the association between atopic conditions and tympanostomy tube placement in children. Allergy Asthma Proc 2012;33(3):289-96. http://dx.doi.org/10.2500/aap.2012.33.3529

\section{Available online at http://www.thepcrj.org}

